\title{
Development and Validation of Methods for the Determination of Aluminum and Lead in Beer Using Multivariate Optimization and GFAAS
}

\author{
Simone Soares de Oliveira ${ }^{a *}$, Waldomiro Borges Neto ${ }^{a}$, Mark Anthony Beinner ${ }^{b}$, \\ and José Bento Borba da Silva ${ }^{c}$ \\ ${ }^{a}$ Department of Chemistry, Institute of Chemistry, Federal University of Uberlândia, \\ 38400-902, Uberlândia, MG, Brazil \\ b School of Nursing and Nutrition, Federal University of Minas Gerais, \\ 30130-100, Belo Horizonte, MG, Brazil \\ c Department of Chemistry, Institute of Exact Sciences, Federal University of Minas Gerais, \\ 31270-901, Belo Horizonte, MG, Brazil
}

\section{INTRODUCTION}

Beer is a result of yeast alcoholic fermentation of extracts of malted cereals, usually barley malts, with or without a starchy material, and to which hops are added. All natural components used for brewing, including water, cereals, barleys, and yeasts, are the main endogenous sources of metals in beer. For this reason, the mineral composition of beer reflects the composition of ingredients used for brewing and refers to processes involved in beer production. The content of metals is variable and depends on the quality of substrates taken, the type of beer brewed, and the beer country of origin (1). Another exogenous source of metals in beer results from contamination of brewery equipment, i.e., pipes, fluid lines, vessels and tanks, used for beer handling, including fermentation, conditioning, filtration, carbonation, and packaging. Also, containers (kegs, casks, cans), in which a final quality product is stored and transported, can be a potential source of beer contamination (1). Indeed, moderately acidic brewing liquors and beer ( $\mathrm{pH} 4.2$ on average) can, to a large extent, contribute to metal ion ingestion, especially in the case of aluminum (Al) cans, kegs, and casks (1).

* Corresponding autbor.

E-mail: simonesob@gmail.com

Tel: +553432394443

\section{ABSTRACT}

In this work, efficient methods to determine aluminum (Al) and lead $(\mathrm{Pb})$ in beer samples by graphite furnace atomic absorption spectrometry (GFAAS), following multivariate optimization, were developed. The only sample preparation used was degassing of the beer to remove $\mathrm{CO}_{2}$. Permanent rhodium ( $\mathrm{Rh}$ ) for aluminum and permanent iridium (Ir) for lead proved to be the better permanent modifier. Optimization included fractional factorial planning using the Pareto and the CCD designs. The working linear range was $0-90 \mu \mathrm{g}$ $\mathrm{L}^{-1}$ for aluminum and $0-60 \mu \mathrm{g} \mathrm{L}^{-1}$ for lead $\left(r^{2}>0.99\right)$. The obtained LOQs were 4.8 and $1.6 \mu \mathrm{g} \mathrm{L}^{-1}$ for aluminum and lead, respectively. Aqueous and matrix-matched calibration curves had average angular coefficients that were not statistically different, i.e., the matrix effect was absent for aluminum, while for lead the coefficients were statistically different. Matrix-matched calibration was used in the subsequent studies for the beer samples. The accuracy was checked by recovery tests with a percentage recovery range of $89-95 \%(\mathrm{n}=45)$ for $\mathrm{Al}$ and 97 to $98 \%$ for $\mathrm{Pb}(\mathrm{n}=45)$. The coefficient of variation (CV) of the intra-assay studies $(\mathrm{n}=15)$ was 4.0 and $2.5 \%$ for $\mathrm{Al}$ and $\mathrm{Pb}$, respectively, where the $\mathrm{CV}$ for the inter-assay studies $(n=45)$ was 3.0 for $\mathrm{Al}$ and $3.1 \%$ for $\mathrm{Pb}$. The $\mathrm{Al}$ and $\mathrm{Pb}$ levels in the 21 beer samples varied from $<$ LOQ of $72.9 \mu \mathrm{g}$ $\mathrm{L}^{-1}$ for $\mathrm{Al}$ and $<\mathrm{LOQ}$ of $8.7 \mu \mathrm{g} \mathrm{L}^{-1}$ for $\mathrm{Pb}$.
Lead $(\mathrm{Pb})$ is a non-essential element. Toxic effects resulting from its extensive use in silver smelting, paint production, jewelry making, ceramic glazes, building construction, and in drinking vessels and water supply systems have been known for hundreds of years. Over the last 150 years, the industrial use of lead has increased enormously, and since the mid-1920s, the use of alkyl lead derivatives as anti-knock agents in petrol has resulted in a massive increase in distribution, only recently curbed by the introduction of "unleaded" petrol (2).

Aluminum is a non-essential element with poisonous properties even at low concentration levels. It is the most abundant metallic element on earth and naturally occurs in certain minerals, ores, oxides, and silicates. Humans are exposed to aluminum on a regular basis through drinking water, various foods, medications, dust, and deodorants. On average, a healthy individual's aluminum exposure causes little harm as a result of pharmacokinetic properties characterized by poor oral bioavailability. The gastrointestinal tract allows less than $1 \%$ of ingested aluminum into the bloodstream. Renal excretion removes $99 \%$ of the aluminum that enters the bloodstream. Despite these protective mechanisms, aluminum toxicity has been documented in the medical literature for over 30 years. Recorded manifestations of aluminum toxicity include fracturing osteomalacia and reduced bone mineralization, neu- 
rological dysfunction and dialysis encephalopathy, microcytic hypochromic anemia, and cholestasis (3).

Due to the low concentrations in a variety of food samples, $\mathrm{Al}$ and $\mathrm{Pb}$ determination requires an accurate analytical method with sufficient sensitivity. Graphite furnace atomic absorption spectrometry (GFAAS) and the plasma techniques have been widely used for total metal determination in several types of food and beverage samples $(4,5)$. Most analytical techniques for metal determination require a sample preparation method that involves solubilization with complete or partial decomposition of the matrix, and most methods make use of acids with oxidizing properties. Alves et al. (6) developed a method to determine low lead concentrations in beer samples using Moringa oleifera seeds as a biosorbent material by solid-phase extraction with a flow injection system and determination by flame atomic absorption spectrometry (FAAS). Under optimized conditions, the preconcentration factor, precision, detection limit, consumption index, and sample throughput were estimated as $93,0.3 \%\left(10.0 \mu \mathrm{g} \mathrm{L}^{-1}\right.$, $\mathrm{n}=7), 7.5 \mu \mathrm{g} \mathrm{L}^{-1}, 0.11 \mathrm{~mL}$, and 23 samples per hour, respectively. The developed method was successfully applied to beer samples, with recoveries ranging from $80 \%$ to $100 \%$.

In this study, two simple methods to determine lead (and cadmium) in different kinds of beverages and vinegar have been developed. Using these methods, it was possible to determine lead accurately by direct analysis in different liquids and to evaluate the leaching of these metals from pewter cups. Leaching experiments have been carried out with different solutions such as beer, sugar cane spirits, red and white wine, vinegar and a 3\% acetic acid solution. The results presented in this work demonstrate that pewter cups are not lead-free, contrary to the manufacturers' declarations that their products are lead-free (7). The hollow fiber liquid-liquid solid microextraction (HF-LLSME) method, which consists of simultaneous liquid-liquid microextraction and polypropylene microporous membrane solid phase micro-extraction procedures to determine $\mathrm{Pb}$ (II) in aqueous solution and soft drink samples, was used to provide low limits of detection, good precision, and linearity. The parameters affecting the extraction efficiency were optimized using a multivariate methodology and the analytical features established. Under optimized conditions, $\mathrm{Pb}$ (II) was concentrated for 20 minutes on three 6-mm long microporous membrane hollow fibers, placed into 20-mL soft drinks containing $60 \mu \mathrm{L}$ of toluene and ammonium O,O-diethyl dithiophosphate. The fibers were introduced directly into the graphite furnace as a solid sample, and the analyte was thermally desorbed from the fiber and atomized using ruthenium as a permanent modifier. A limit of detection of $7 \mathrm{ng} \mathrm{L}^{-1} \mathrm{~Pb}$ was obtained for soft drink samples, and good repeatability was found for all samples. The enrichment factor varied between 22 and 66, regardless whether only one or all three of the hollow fibers were used for lead determination. The proposed method is simple, effective, low cost, uses just microliters of organic solvents, is almost free of matrix effects, and completely avoids the problems associated with carryover. Furthermore, the proposed combination of the extraction systems results in improved extraction efficiency. To the best of our knowledge, this constitutes the first study that applies simultaneous liquid-liquid microextraction (LLME) and polypropylene microporous membrane (SPME) as a preconcentration procedure to determine metal ions.

\section{Atomic}

It may be assumed that this system can also be used for the extraction of other trace elements from a variety of other matrices (8).

The thermospray flame furnace atomic absorption spectrometry (TS-FF-AAS) system has been used for trace metal determination in beer. The sensitivity obtained by TS-FF-AAS allowed direct analysis of the beer samples prepared just by degasification and dilution. The analyte addition technique led to accurate results for $\mathrm{Pb}$ amongst other metals ( $\mathrm{Cu}, \mathrm{Mn}$, and $\mathrm{Zn}$ ) in beer, whereas the standard calibration technique with reference solutions, prepared in aqueous medium, resulted in low recoveries for all elements due to matrix effects. No digestion was required and, therefore, time and reagent consumption were minimized, in addition to improved safety. Thermospray-FFAAS presents lower cost and can be easily implemented. Additionally, TS-FF-AAS can expand the applicability of the widely available FAAS instruments (9). But it should be noted that the sensitivity of this equipment is much lower when compared to GFAAS.

Table I lists examples of studies performed for the determination of different metals in beverage samples.

In this paper, a simple, fast, and reliable method is proposed for the determination of $\mathrm{Al}$ and $\mathrm{Pb}$ in beer samples without any sample preparation. This method only requires degassing of the beer samples and selection of the most appropriate modifier for the determination of $\mathrm{Al}$ and $\mathrm{Pb}$ by GFAAS. A literature search showed that for the quantification of metals in beer generally very exhaustive preliminary treatments, large amounts of reagents, and an apparatus (like an analytical microwave) need to be used, which are costly and time-consuming and require skilled labor (1). 
TABLE I

Comparison of Methods to Determine $\mathrm{Al}$ and $\mathrm{Pb}$ (and other metals) in Beverage Samples

\begin{tabular}{|c|c|c|c|c|c|c|}
\hline \multicolumn{2}{|c|}{ Samples Analytes } & \multirow{2}{*}{$\begin{array}{l}\text { Methods } \\
\text { Preconcentration using Molinga } \\
\text { Oleifera (SPE) }\end{array}$} & \multirow{2}{*}{$\begin{array}{l}\text { Analytical } \\
\text { Technique } \\
\text { FAAS }\end{array}$} & \multirow{2}{*}{$\begin{array}{l}\begin{array}{c}\mathrm{LOD} \\
\left(\mu \mathrm{g} \mathrm{L}^{-1}\right)\end{array} \\
7.5\end{array}$} & \multirow{2}{*}{$\begin{array}{l}\text { Accuracy and } \\
\text { Precision } \\
\text { Recoveries of spiked } \\
\text { samples between } \\
80.7 \text { to } 112.0 \%\end{array}$} & ference \\
\hline Beer & $\begin{array}{l}\mathrm{Pb} \\
(6)\end{array}$ & & & & & (6) \\
\hline $\begin{array}{l}\text { Beverages } \\
\text { and vinegar }\end{array}$ & $\mathrm{Cd}, \mathrm{Pb}$ & $\begin{array}{l}\text { Methods have been developed to } \\
\text { determine the metals in different } \\
\text { kinds of beverages and vinegar } \\
\text { leached from pewter cups } \\
\text { produced in Brazil. }\end{array}$ & $\begin{array}{l}\text { GFAAS with } \\
10 \mu \mathrm{L} \text { of } 0.1 \% \mathrm{Pd}+ \\
0.06 \% \mathrm{Mg} \text { solution }\end{array}$ & $\begin{array}{l}1.4 \\
(\mathrm{~Pb})\end{array}$ & $\begin{array}{l}\text { Comparison with direct } \\
\text { GFAAS and acid digested } \\
\text { procedure were in } \\
\text { good agreement }\end{array}$ & (7) \\
\hline $\begin{array}{l}\text { Water } \\
\text { and soft } \\
\text { drinks }\end{array}$ & $\mathrm{Pb}$ & $\begin{array}{l}\text { Hollow-fiber liquid-liquid- } \\
\text { solid micro-extraction technique } \\
\text { based on simultaneous liquid } \\
\text { liquid micro-extraction and solid } \\
\text { phase micro-extraction using a } \\
\text { polypropylene microporous membra }\end{array}$ & $\begin{array}{l}\text { GFAAS with Ru as } \\
\text { permanent modifier }\end{array}$ & 0.007 & $\begin{array}{l}\text { Recoveries of spiked } \\
\text { soft drink samples } \\
\text { between } 85 \text { to } 100 \%\end{array}$ & (8) \\
\hline Beer & $\begin{array}{l}\mathrm{Pb}, \mathrm{Cu}, \\
\mathrm{Mn}, \mathrm{Zn}\end{array}$ & $\begin{array}{l}\text { Sample volume of } 300 \mu \mathrm{L} \text { was } \\
\text { introduced into the hot Ni tube } \\
\text { at a flow rate of } 0.4 \mathrm{~mL} \text { min }^{-1} \text { using } \\
0.14 \mathrm{~mol} \mathrm{~L}^{-1} \text { nitric acid solution } \\
\text { or air as carrier. Calibration was } \\
\text { made using standard addition. }\end{array}$ & TS-FF-AAS & $\begin{array}{l}1.6 \\
(\mathrm{~Pb})\end{array}$ & $\begin{array}{l}\text { Comparison of } 4 \text { kinds } \\
\text { of beer by GFAAS are in } \\
\text { agreement with proposed } \\
\text { method }\end{array}$ & (9) \\
\hline $\begin{array}{l}\text { Beer and } \\
\text { wine }\end{array}$ & $\begin{array}{l}\mathrm{Pb}, \mathrm{Cu}, \\
\mathrm{Cu}, \mathrm{Cd}\end{array}$ & $\begin{array}{l}\text { Polish the glassy carbon } \\
\text { electrode for a few seconds } \\
\text { on } 3 \text { - } \mu \text { m diamond paste, wash with } \\
\text { acetone, and insert in the electro } \\
\text { chemical cell. Transfer sample to } \\
\text { electrochemical cell and adjust the } \\
\text { potentiostatic circuitry to }-0.9 \mathrm{~V} \text { vs. } \\
\text { SCE. Calibration with standard additi }\end{array}$ & $\begin{array}{l}\text { Potentiometric } \\
\text { stripping analysis } \\
\text { ion. }\end{array}$ & $\begin{array}{l}\text { No } \\
\text { data }\end{array}$ & $\begin{array}{l}\text { Accuracy in the potentio- } \\
\text { metric stripping analysis } \\
\text { of wine was tested by } \\
\text { comparison with AAS. } \\
\text { Discrepancy of results } \\
\text { never exceeded } 1.5 \%\end{array}$ & (40) \\
\hline $\begin{array}{l}\text { Beer, wine } \\
\text { and other } \\
\text { beverages }\end{array}$ & $\mathrm{Al}$ & $\begin{array}{l}5.0-\mathrm{mL} \text { sample was treated with } \\
1 \mathrm{~mL} \text { of } 65 \% \mathrm{v} / \mathrm{v} \mathrm{HNO}_{3} \text { and } 30 \mu \mathrm{g} \\
\mathrm{V}_{2} \mathrm{O}_{5} \text { and heated at } 120^{\circ} \mathrm{C} \text { for } 90 \mathrm{~min} \\
\text { in digestion block. The solution } \\
\text { was diluted to a final volume of } \\
10.0 \mathrm{~mL} \text { with deionized water. } \\
\text { Al was determined in the resulting } \\
\text { solution by GFAAS. }\end{array}$ & $\begin{array}{l}\text { GFAAS, using } 50 \mu \mathrm{g} \\
\mathrm{Mg}\left(\mathrm{NO}_{3}\right)_{2} \text { modifier }\end{array}$ & 4.0 & $\begin{array}{l}\text { Mean recovery of } \\
98.25 \%\end{array}$ & (48) \\
\hline $\begin{array}{l}\text { Soft } \\
\text { Drinks }\end{array}$ & $\mathrm{Al}$ & $\begin{array}{l}\text { Comparative study of conventional } \\
\text { and multivariate methods for } \mathrm{Al} \\
\text { determination. }\end{array}$ & $\begin{array}{l}\text { GFAAS using } \mathrm{Zr} \\
\text { permanent }(500 \mu \mathrm{g}) \\
\text { modifier }\end{array}$ & $\begin{array}{l}17.9 \\
\mathrm{CM} \\
11.3 \\
\mathrm{MO}\end{array}$ & $\begin{array}{l}\text { Recovery studies } \\
98-107 \%(\mathrm{CM}=\text { convention } \\
\text { method) and } 93-103 \% \\
(\mathrm{MO}=\text { multivariate optimiz }\end{array}$ & $\begin{array}{l}(37) \\
\text { ation) }\end{array}$ \\
\hline Beer & $\mathrm{Al}, \mathrm{Pb}$ & $\begin{array}{l}\text { Direct analysis after degasification } \\
\text { and after chemometric } \\
\text { optimization }\end{array}$ & $\begin{array}{l}\text { GFAAS using } \\
\text { permanent } \mathrm{Rh} \\
(500 \mu \mathrm{g}) \text { for } \mathrm{Al} \\
\text { and permanent } \mathrm{Ir} \\
(500 \mu \mathrm{g}) \text { for } \mathrm{Pb}\end{array}$ & $\begin{array}{l}4.8 \\
(\mathrm{Al}) \\
1.6 \\
(\mathrm{~Pb})\end{array}$ & $\begin{array}{l}\text { Accuracy was checked } \\
\text { by recovery ( } 89-95 \% \\
\mathrm{n}=45) \text { for } \mathrm{Al} \text {, and } 97-98 \% \\
\text { for } \mathrm{Pb} \text {. The } \mathrm{CV} \text { of variatior } \\
\text { of intra- }(\mathrm{n}=15) \text { and inter- } \\
\text { assay studies }(\mathrm{n}=45) \text { was } \\
4.0 \text { and } 2.5 \% \text { for } \mathrm{Al} \text { and } \mathrm{Pb} \\
\text { and of } 3.0 \text { and } 3.1 \% \text { for } \mathrm{Al} \\
\mathrm{Pb} \text { for intra- an inter-assay }\end{array}$ & and \\
\hline
\end{tabular}




\section{EXPERIMENTAL}

\section{Instrumentation}

Measurements were carried out using a PerkinElmer ${ }^{\circledR}$ AAnalyst ${ }^{\mathrm{TM}}$ 400 atomic absorption spectrometer (PerkinElmer, Inc., Shelton, CT, USA), equipped with a graphite furnace (HGA ${ }^{\circledR}$ 900), an autosampler (AS-800), and a deuterium lamp arc continuum background corrector. Except for the optimized conditions, the instrument was operated according to the manufacturer's guidelines. GFAAS was chosen due to its excellent detection limits and low sample demand.

An aluminum hollow cathode lamp (PerkinElmer, Inc.) was operated at $25 \mathrm{~mA}$ with a spectral bandpass of $2.7 / 0.8 \mathrm{~nm}$ at $309.27 \mathrm{~nm}$. A PerkinElmer ${ }^{\circledR}$ hollow cathode lamp, operated at $10 \mathrm{~mA}$, with a spectral bandpass of $2.7 / 1.05 \mathrm{~nm}$ and at $193.7 \mathrm{~nm}$, was used for lead. Argon 99.996\% (White Martins, Belo Horizonte, MG, Brazil) was used as the purge gas at a flow rate of $250 \mathrm{~mL} \mathrm{~min}^{-1}$. PerkinElmer ${ }^{\circledR}$ graphite tubes with integrated platforms (Part Numbers B3001264 and B3001263) were used for all studies.

The final volume of the samples and the calibration solutions placed onto the graphite tubes was $20 \mu \mathrm{L}$. To study the best permanent modifier for each investigated element, each tube was previously treated with rhodium (Rh), iridium (Ir), ruthenium $(\mathrm{Ru})$, zirconium $(\mathrm{Zr})$, tungsten (W), tantalum (Ta), titanium (Ti), and niobium ( $\mathrm{Nb}$ ) by adding $50 \mu \mathrm{L}$ of $1000 \mu \mathrm{g} \mathrm{L}^{-1}$ of each solution and heating the tube with a specific temperature program $(10,11)$. This procedure was repeated 10 times to obtain a $500-\mu \mathrm{g}$ deposit of the permanent modifier on the platform inside the graphite furnace. The condition without modifier was also studied. The lifetime of the graphite tube using a permanent modifier without a decrease in sensitivity is more than 1000 cycles $(11,12-14)$; however, this was not investigated in this study.

In all experiments and to obtain the best analytical conditions for $\mathrm{Al}$ and $\mathrm{Pb}$ determination, preferably without any interference, the beer samples were degasified. The beer samples used in all optimization processes received code BN12, which permitted to identify when the $\mathrm{Al}$ concentration exceeded $30 \mu \mathrm{g} \mathrm{L}^{-1}$. The same beer samples were used in the next experiments for $\mathrm{Pb}$, but in addition, were spiked with $30 \mu \mathrm{g} \mathrm{L}^{-1}$ of this metal.

The optimized graphite furnace temperature program for the determination of $\mathrm{Al}$ and $\mathrm{Pb}$ in beer samples is presented in Table II. The use of a permanent modifier has become an important tool since it is considered more appropriate than conventional modifiers, such as those based on Pd and Mg. Furthermore, since the modifier is impregnated in the graphite tube or on the platform, it is no longer necessary to add a modifier to each sample, which represents an improvement in the limit of detection, in addition to reducing cost analysis (15).

The use of permanent modifiers also demonstrates good selectivity, sensitivity, and the possibility of direct analysis with minimal or no sample preparation (16-39). In addition to the advantages of the GFAAS technique, use of permanent modi-

\section{Atomic Apectroscopy \\ Vol. 37(2), March/April 2016}

fiers improves the thermal stability of the analyte, allows for higher pyrolysis temperatures, and consequently, a better elimination of the matrix (15). In most cases, permanent modification also extends the lifetime of the graphite tube. This technique can additionally be used for various kinds of specie samples such as environmental, sediment, biological, food, suspension, fuel, drug, etc. Our research group has had excellent results with the use of permanent modifiers in different matrices analyzed by GFAAS, such as clinical $(12,17-20,23-27,31)$, biological $(11,21)$, environmental samples $(10,32-34)$, as well as beverages $(35,37)$, foods $(4,16,28$ $30)$, drugs $(38,39)$, and others (22, 36).

\section{Reagents and Solutions}

For this study, the following reagents were used: Suprapur ${ }^{\circledR}$ nitric acid, 65\% (Merck, Darmstadt, Germany); iridium, niobium, tantalum, titanium ruthenium, rhodium and zirconium solutions (1000 $\mathrm{mg}$ $\mathrm{L}^{-1}$ ) (Fluka, Buchs, Switzerland) at $1 \mathrm{~mol} \mathrm{~L}^{-1}$ in hydrochloric acid. Tungsten standard solution $\left(1.0 \mathrm{~g} \mathrm{~L}^{-1}\right.$ W) was prepared by dissolving $0.18 \mathrm{~g}$ of $\mathrm{Na}_{2} \mathrm{WO}_{4}$ (Merck) in $100 \mathrm{~mL}$ of water. The aluminum and lead analytical solutions were prepared from stock solutions of $1000 \mathrm{mg} \mathrm{L}^{-1}$ prepared using $5 \%(\mathrm{v} / \mathrm{v})$ nitric acid from ampoules (Titrisol ${ }^{\circledR}$, Merck, Germany) and stored according to the manufacturer's instructions.

TABLE II

Temperature Program for the Determination of $\mathbf{A l}$ and $\mathbf{P b}$ in Beer Samples by GFAAS with $R^{\mathrm{a}}{ }^{\mathrm{a}}$ and $\mathrm{Ir}^{\mathrm{b}}$ as Permanent Modifier

\begin{tabular}{lrrrr}
\hline Step & $\begin{array}{c}\text { Temperature } \\
\left({ }^{\circ} \mathrm{C}\right)\end{array}$ & $\begin{array}{c}\text { Ramp } \\
(\mathrm{s})\end{array}$ & $\begin{array}{c}\text { Hold } \\
(\mathrm{s})\end{array}$ & $\begin{array}{c}\text { Air Flow Rate } \\
\left(\mathrm{mL} \mathrm{min}^{-1}\right)\end{array}$ \\
\hline Dry & 100 & 5 & 20 & 250 \\
Dry & 140 & 15 & 15 & 250 \\
Pyrolysis & $1180^{\mathrm{a}}, 960^{\mathrm{b}}$ & 10 & 20 & 250 \\
Atomization & $2640^{\mathrm{a}}, 1900^{\mathrm{b}}$ & 0 & 5 & 0 (read) \\
Clean & 2600 & 1 & 5 & 250 \\
\hline
\end{tabular}

${ }^{\mathrm{a}} \mathrm{Al}$ and ${ }^{\mathrm{b}} \mathrm{Pb}$. 
The solutions were prepared with deionized water with a specific resistivity of $18 \mathrm{~m} \Omega \mathrm{cm}^{-1}$ obtained by double-filtering distilled Milli-Q ${ }^{\circledR}$ water purifier (Model RO15, Millipore Corporation, France) immediately before use. Triton ${ }^{\circledR}$-X100 $(0.2 \% \mathrm{~m} / \mathrm{v})$ (Sigma-Aldrich, USA) was used as a diluent and detergent in the cleaning solution to eliminate carbonaceous residues forming inside the graphite tube. This also helps in the cleaning of the capillary autosampler in between sampling.

All glassware and autosampler cups were washed thoroughly with a detergent solution, rinsed with bath of $50 \%(\mathrm{v} / \mathrm{v})$ nitric acid for at least 24 hours, and rinsed several

\section{Procedure and Samples}

The beer samples were purchased in Belo Horizonte-MG, Brazil, at liquor stores specializing in the sale of domestic and imported beverages. Degasification of beer can be done by shaking or rapidly transferring it from one beaker to another. The number of repetitions to eliminate foam from a sample will depend on the sample type, temperature, as well as other factors. However, this procedure is facilitated when the sample temperature is at around $25^{\circ} \mathrm{C}$. The deionized water, maintained in a times with deionized water. accuracy of the proposed methodologies was achieved by spiking the beer samples at different levels. The spikes were made in beer samples immediately after degasification in volumetric flasks by adding appropriate volumes of acidified solution $(2 \% \mathrm{v} / \mathrm{v})$ of each of the metals. The recovery studies were performed by spiking a pool of beer samples with 20, 50, and 80 $\mu \mathrm{g} \mathrm{L^{-1 }}$ of aluminum, and 15,30 , and $55 \mu \mathrm{g} \mathrm{L}^{-1}$ of lead. These solutions were prepared daily over three consecutive days in five replicates and read in triplicate. The limits of detection and quantification (LOD and LOQ, $\mu \mathrm{g} \mathrm{L}^{-1}$ ) were calculated using the following equations: LOD $=3 \mathrm{~s} / \mathrm{b}$, and LOQ $=10 \mathrm{~s} / \mathrm{b}$, where $\mathrm{s}$ is the standard deviation of 10 measurements of the blank of the calibration curves, and $b$ is the slope of these curves.

\section{Optimization Strategies}

The best modifier in both the factorial and the central composite design (CCD) for aluminum and lead in beer was selected by using the furnace temperature program as recommended by the instrument manufacturer. The permanent modifiers tested were $\mathrm{Rh}, \mathrm{Ir}, \mathrm{Ru}, \mathrm{Zr}, \mathrm{W}$, $\mathrm{Ta}, \mathrm{Ti}$, and $\mathrm{Nb}(500 \mu \mathrm{g}$ of each on the graphite tube platform). The condition without modifier was also applied. The two best modi- fiers (highest sensitivity, RSD $\mathrm{n}=3$ better than $5 \%$, good peak profilesymmetrically, corrected background absorbance) were the permanent modifiers of $\mathrm{Zr}$ and $\mathrm{Rh}$ for $\mathrm{Al}$ and $\mathrm{Pb}$, respectively.

Two full factorial designs were carried out to examine the influence of and interactions with the studied variables in addition to determining the optimal experimental conditions for $\mathrm{Al}$ and $\mathrm{Pb}$. In the first full factorial design, presented in (Table III) for the $2^{3}=8$ experiments in triplicate, the factors studied were pyrolysis temperatures (PT) at 1500 and $2100{ }^{\circ} \mathrm{C}$, atomization temperatures (AT) at 2300 and $2700{ }^{\circ} \mathrm{C}$, and the permanent modifiers $\mathrm{Rh}$ or $\mathrm{Zr}$ for aluminum. In the second full factorial design (Table IV), using $2^{3}=8$ experiments in triplicate, the studied variables were pyrolysis temperatures (PT) at 500 and 1500 ${ }^{\circ} \mathrm{C}$, atomization temperatures (AT) at 2000 and $2700{ }^{\circ} \mathrm{C}$, and permanent Ir and $\mathrm{Ru}$ for lead. The two best modifiers for each analyte were employed in the next experimental designs (CCDs).

The integrated absorbance (peak area) was used as a response and the experimental data were processed using the Statistica ${ }^{\mathrm{TM}}$ software version 7.0 (Dell, Inc.) (41).

TABLE IV Matrix of Full Factorial Design $2^{3}$ for $\mathrm{Pb}\left(20 \mu \mathrm{g} \mathrm{L^{-1 }}\right)$ Matrix of Full Factorial Design $2^{3}$ for Al $\left(20 \mu \mathrm{L} \mathrm{L}^{-1}\right)$

\begin{tabular}{|c|c|c|c|c|}
\hline Assay & $\begin{array}{c}\text { Pyrolysis } \\
\text { Temp } \\
{ }^{\circ} \mathrm{C}\end{array}$ & $\begin{array}{l}\text { Atomiaztion } \\
\text { erature } \\
{ }^{\circ} \mathrm{C}\end{array}$ & $\underset{\mathrm{r}}{\text { Modifier }}$ & $\begin{array}{c}\text { Absorbance }^{\mathrm{a}} \\
\text { Mean } \\
(\mathrm{n}=3)\end{array}$ \\
\hline 1 & $2100(+)$ & $2300(-)$ & $\mathrm{Zr}(+)$ & 0.108 \\
\hline 2 & $2100(+)$ & $2700(+)$ & $\mathrm{Zr}(+)$ & 0.262 \\
\hline 3 & $1500(-)$ & $2300(-)$ & $\mathrm{Zr}(+)$ & 0.164 \\
\hline 4 & $1500(-)$ & $2700(+)$ & $\mathrm{Zr}(+)$ & 0.387 \\
\hline 5 & $2100(+)$ & $2300(-)$ & $\mathrm{Rh}(+)$ & 0.153 \\
\hline 6 & $2100(+)$ & $2700(+)$ & $\mathrm{Rh}(+)$ & 0.562 \\
\hline 7 & $1500(-)$ & $2300(-)$ & $\mathrm{Rh}(+)$ & 0.220 \\
\hline 8 & $1500(-)$ & $2700(+)$ & $\mathrm{Rh}(+)$ & 0.829 \\
\hline
\end{tabular}

*Average measured in triplicate.

\begin{tabular}{llccc}
\hline Assay & $\begin{array}{c}\text { Atomization } \\
\text { Temperature }\end{array}$ & $\begin{array}{c}\text { Pyrolysis } \\
{ }^{\circ} \mathrm{C}\end{array}$ & $\begin{array}{c}\text { Modifier } \\
\mathrm{r}\end{array}$ & $\begin{array}{c}\text { Absorbance } \\
\text { Mean }\end{array}$ \\
\hline 1 & $2000(-)$ & $500(-)$ & $\operatorname{Ir}(-)$ & 0.653 \\
2 & $2700(+)$ & $500(-)$ & $\operatorname{Ir}(-)$ & 0.561 \\
3 & $2000(-)$ & $1500(+)$ & $\operatorname{Ir}(-)$ & 0.008 \\
4 & $2700(+)$ & $1500(+)$ & $\operatorname{Ir}(-)$ & 0.022 \\
5 & $2000(-)$ & $500(-)$ & $\mathrm{Ru}(+)$ & 0.546 \\
6 & $2700(+)$ & $500(-)$ & $\mathrm{Ru}(+)$ & 0.527 \\
7 & $2000(-)$ & $1500(+)$ & $\mathrm{Ru}(+)$ & 0.001 \\
8 & $2700(+)$ & $1500(+)$ & $\mathrm{Ru}(+)$ & 0.008 \\
\hline
\end{tabular}

*Average measured in triplicate. 


\section{RESULTS AND DISCUSSION}

\section{Multivariate Optimization}

According to the results obtained from the two best modifier choices for aluminum and lead, two full factorial designs were performed (Tables III and IV) to conduct a preliminary evaluation of the variables PT, AT, and modifier type (permanent $\mathrm{Zr}$ or $\mathrm{Rh}$ for aluminum and permanent Ir or Ru for lead).

The results of the factorial design for $\mathrm{Al}$ and $\mathrm{Pb}$ are presented using the Pareto chart for the estimated effects (Figures 1 and 2, respectively). All variables and their interactions showed significant effects to the response (integrated absorbance) at a 95\% confidence level for both analytes, and best results were obtained with a positive tendency of atomization temperature (AT) at $2700{ }^{\circ} \mathrm{C}$, negative tendency of pyrolysis temperature (PT) at $1500{ }^{\circ} \mathrm{C}$, and rhodium as the permanent modifier for $\mathrm{Al}$ (Figure 1). In examining lead, best results were obtained with a negative tendency of AT at $2000{ }^{\circ} \mathrm{C}$, a negative tendency of PT at $500{ }^{\circ} \mathrm{C}$, and permanent iridium as the modifier (Figure 2).

\section{Atomic Spectroscopy \\ $\bigcup$ Vol. 37(2), March/April 2016}

Fixing a permanent rhodium modifier for $\mathrm{Al}$ and using a permanent Ir modifier for $\mathrm{Pb}$, a second study was performed using a CCD design to refine PT and AT (Tables $\mathrm{V}$ and VI). The blanks were analyzed in three replicates for the analytical calibration curves and in 10 replicates for the LOD and LOQ calculation. The integrated absorbance values were lower than 0.007 for $\mathrm{Al}$ and lower than 0.006 for $\mathrm{Pb}$.

A response surface methodology, using a central composite design for $\mathrm{Al}$ (Figure 3) and $\mathrm{Pb}$
TABLE V Matrix of CCD Design for Al in Beers

\begin{tabular}{llll}
\hline Assay & $\begin{array}{c}\text { Atomization } \\
\text { Temperature } \\
\left({ }^{\circ} \mathrm{C}\right)\end{array}$ & $\begin{array}{c}\text { Pyrolysis } \\
(2530(-)\end{array}$ & $\begin{array}{c}\text { Integrated } \\
\text { Absorbance } \\
(\text { s })\end{array}$ \\
\hline 1 & $1100(-)$ & 0.054 \\
2 & $2530(-)$ & $1300(+)$ & 0.108 \\
3 & $2670(+)$ & $1100(-)$ & 0.167 \\
4 & $2670(+)$ & $1300(+)$ & 0.162 \\
5 & $2500(-)$ & $1200(0)$ & 0.079 \\
6 & 2700() & $1200(0)$ & 0.188 \\
7 & $2600(0)$ & $1060(-)$ & 0.180 \\
8 & $2600(0)$ & 1340() & 0.153 \\
PC(5x) & $2600(0)$ & $1200(0)$ & 0.193 \\
\hline
\end{tabular}

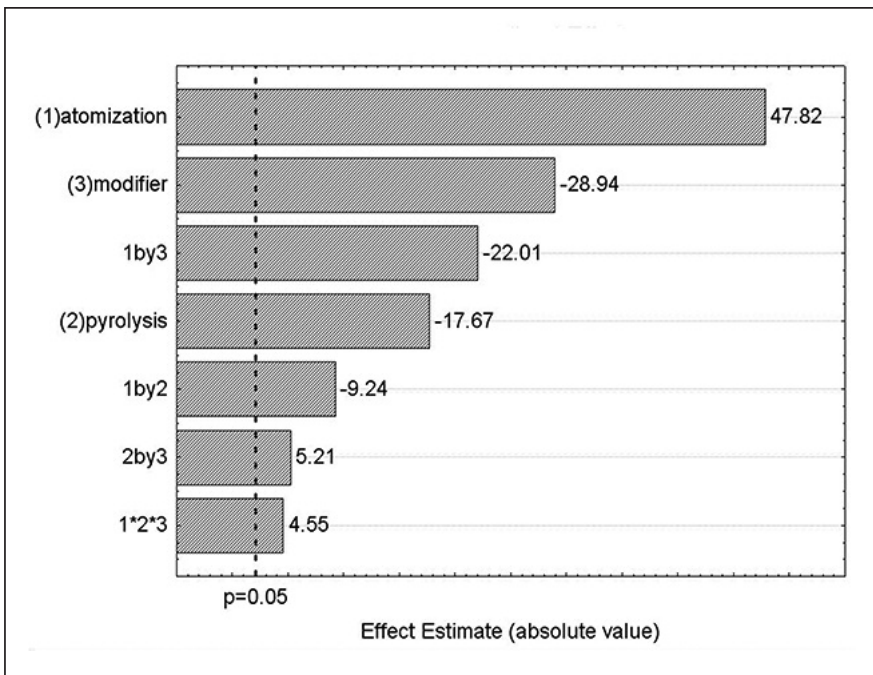

Fig. 1. Pareto chart for the full factorial design (23) for Al.
TABLE VI

Matrix of CCD Design for $\mathrm{Pb}$ in Beers

\begin{tabular}{cccc}
\hline Assay & $\begin{array}{c}\text { Atomization } \\
\text { Temperature } \\
\left({ }^{\circ} \mathrm{C}\right)\end{array}$ & $\begin{array}{c}\text { Pyrolysis } \\
\left({ }^{\circ} \mathrm{C}\right)\end{array}$ & $\begin{array}{c}\text { Integrated } \\
\text { Absorbance } \\
(\mathrm{s})\end{array}$ \\
\hline 1 & $1650(-)$ & $700(-)$ & 0.863 \\
2 & $1950(+)$ & $700(-)$ & 1.284 \\
3 & $1650(-)$ & $1300(+)$ & 0.682 \\
4 & $1950(+)$ & $1300(+)$ & 1.245 \\
5 & $1800(0)$ & $580(-)$ & 1.360 \\
6 & $1800(0)$ & 1420() & 1.302 \\
7 & $1590(-)$ & $1000(0)$ & 0.612 \\
8 & 2010() & $1000(0)$ & 1.456 \\
$\operatorname{PC}(5 x)$ & 1800 & 1000 & 1.363 \\
\hline
\end{tabular}

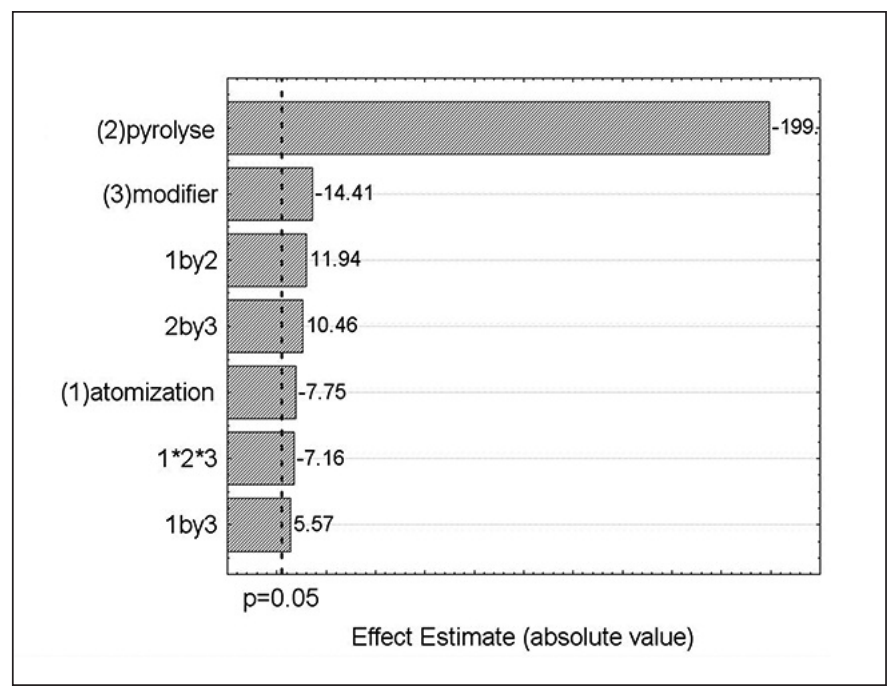

Fig. 2. Pareto chart for the full factorial design $\left(2^{3}\right)$ for $\mathrm{Pb}$. 
(Figure 4) with PT and AT was carried out to optimize and determine the critical points of these variables. The measurement effects of these variables related to response and interactions were based on these results. The AT and its quadratic interaction showed significant effects ( $95 \%$ confidence level). This was true for both $\mathrm{Al}$ and $\mathrm{Pb}$. A quadratic model was obtained after testing for adequacy and fitness using analysis of variance. Regression coefficients and the Pareto charts were obtained after treatment, where the quadratic sum of the residuals was smaller than 0.0020. The suitable polynomial equation was expressed as the surface and contour plots in order to visualize the optimal conditions. With the analysis of the contour surface based on the response surface (Figures 3 and 4), a higher sensitivity was observed in equations 1 and 2, where mathematical functions for the resulting surfaces are presented in Figures 3 and 4. Starting from the derivatives, the optimum conditions for pyrolysis and atomization temperatures, respectively, reached $2640{ }^{\circ} \mathrm{C}$ and 1180 ${ }^{\circ} \mathrm{C}$ for $\mathrm{Al}$ and $1900{ }^{\circ} \mathrm{C}$ and $960{ }^{\circ} \mathrm{C}$ for $\mathrm{Pb}$.

Eq. 1.

$$
\begin{aligned}
\text { Abs }= & -65.267+0.045 \mathrm{TA}- \\
& 0.000008 \mathrm{TA}^{2}+0.010 \mathrm{TP}- \\
& 0.000002 \mathrm{TP}^{2}+ \\
& 0.000002 \mathrm{TATP}
\end{aligned}
$$

Eq. 2.

$$
\begin{aligned}
\mathrm{Abs}= & -29.428-0.0005 \mathrm{TP}- \\
& 0.0000006 \mathrm{TP}^{2}+0.033 \mathrm{TA}- \\
& 0.000009 \mathrm{TA}^{2}+ \\
& 0.0000008 \mathrm{TPTA}
\end{aligned}
$$

By analyzing the background signals, it was possible to confirm that under these conditions of pyrolysis and atomization temperatures, with permanent Rh as modifier for $\mathrm{Al}$ or permanent Ir use for
$\mathrm{Pb}$, there were no problems encountered with background absorption.

After these analyses, permanent $\mathrm{Rh}$ and Ir were the chemical modifiers used for aluminum and lead, respectively, in all subsequent studies.

Table VII presents the optimal experimental conditions obtained by the multivariate procedure for the determination of $\mathrm{Al}$ and $\mathrm{Pb}$ in beer samples using GFAAS. Under these conditions, the background (corrected by deuterium arc lamp) was lower than 0.10 units of absorbance.

\section{TABLE VII \\ Optimized Experimental Conditions Obtained by Multivariate Procedure for the Determination of $\mathrm{Al}$ and $\mathrm{Pb}$ in Undiluted Beer Samples}

\begin{tabular}{lll}
\hline Parameter & $\begin{array}{l}\text { Optimized } \\
\text { Conditionsl } \\
\text { for Al }\end{array}$ & $\begin{array}{l}\text { Optimized } \\
\text { Conditions } \\
\text { for } \mathrm{Pb}\end{array}$ \\
\hline $\begin{array}{l}\text { Modifier } \\
\begin{array}{l}\text { Dilution Factor } \\
\text { Pyrolysis }\end{array}\end{array}$ & $\begin{array}{l}\text { Rodium }(\mathrm{Rh}) \\
\begin{array}{l}\text { Iridium (Ir) } \\
\text { Temperature }\end{array}\end{array}$ & No \\
$\begin{array}{l}\text { Atomization } \\
\text { Temperature }\end{array}$ & $1180^{\circ} \mathrm{C}$ & $960^{\circ} \mathrm{C}$ \\
\hline
\end{tabular}

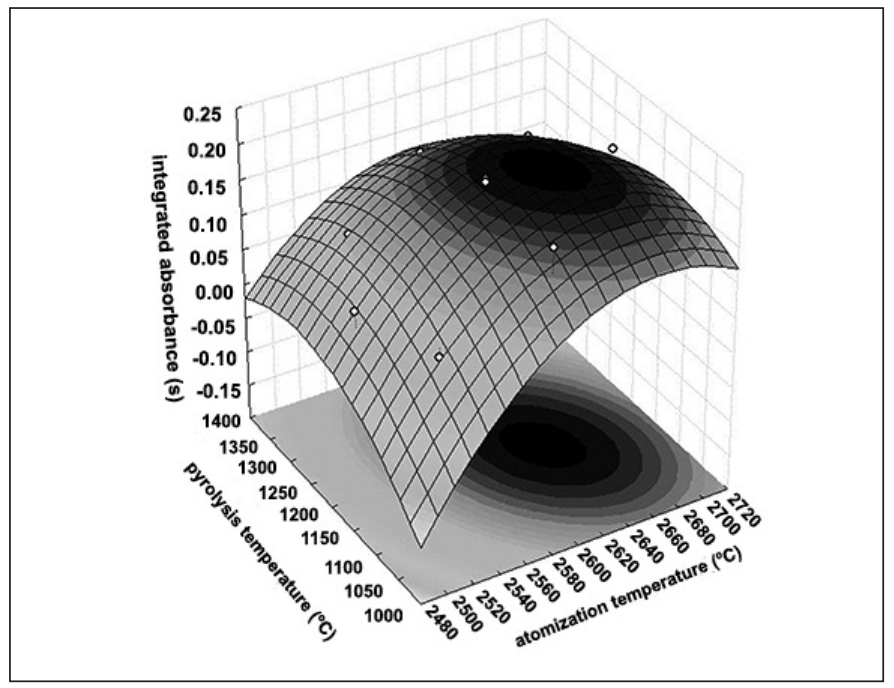

Fig. 3. Response surface obtained in the CCD design for Al in beers.

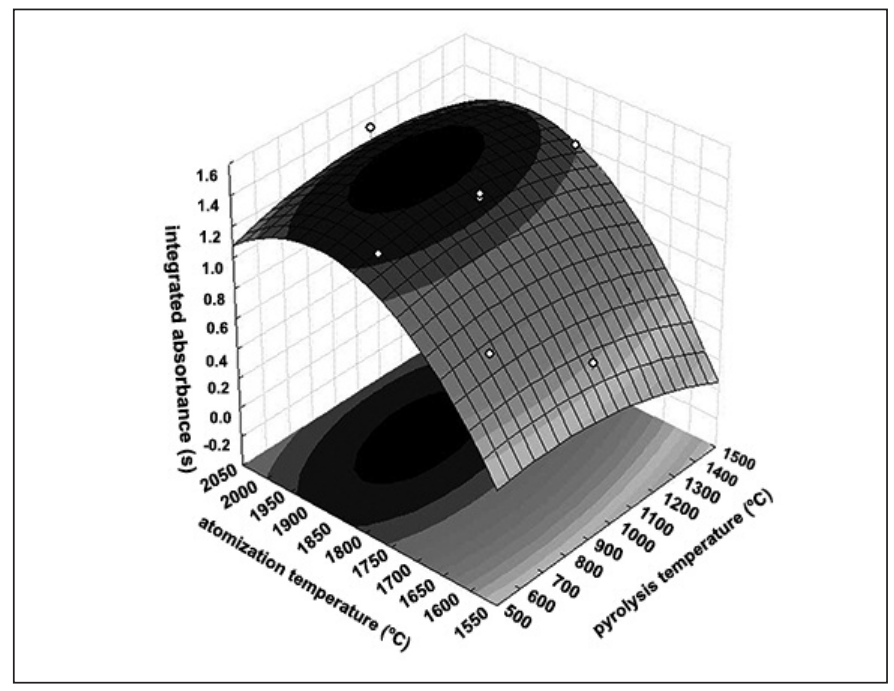

Fig. 4. Response surface obtained in the CCD design for Pb in beers. 


\section{Analytical Figures of Merit}

Under the optimal conditions, the analytical parameters were evaluated. Three aqueous calibration curves and three standard addition calibration curves were built in a water and a beer sample for $\mathrm{Al}$ and $\mathrm{Pb}$. The average slopes of these curves were compared, and for $\mathrm{Al}$ both average slopes were very close, with no significant difference at the $95 \%$ confidence level. Thus, aqueous calibration was utilized in the following determination for aluminum. For lead, using the $\mathrm{F}$ - and Student's $t$-tests, significant differences were observed for the average slopes of the two different curves. The matrix-matched calibration curve was used in subsequent studies for $\mathrm{Pb}$ determination in beer samples.

Precision was measured as a coefficient of variation (\%) for studies of repeatability and reproducibility. Five replicates of pooled beer samples, spiked at three levels on the same day for $\mathrm{Al}$ and $\mathrm{Pb}$ $(n=15)$ and repeating this same study for three consecutive days, were used to study the coefficient of variation for inter-assay precision $(\mathrm{n}=45)$. For the intra-assay, five replicates at each concentration level $\left(30,50\right.$, and $80 \mu \mathrm{g} \mathrm{L} \mathrm{L}^{-1}$ of $\mathrm{Al}$ and 15,30 , and $55 \mu \mathrm{g} \mathrm{L}^{-1}$ of $\mathrm{Pb}$ ) were analyzed on the same day. For the inter-assay studies, the same original solution was prepared in five replicates for each concentration over three days for quality control purposes.

The figures of significance in the present study were determined using an aqueous calibration curve between 0 and $90 \mu \mathrm{g} \mathrm{L}^{-1}$ of $\mathrm{Al}$, which presented an average linear correlation coefficient of $0.9966 \pm$ 0.0036 for aluminum and $0.9947 \pm$ 0.0023 for lead. The calibration curve produced a satisfactory linear correlation coefficient according to the minimum acceptable criterion for the correlation coefficient, which should be AS $=0.99$ for the determination coefficient $\left(\mathrm{R}^{2}\right)$ (42).

Equations for LOD and LOQ were calculated as previously described. The values obtained were $\mathrm{LOD}=1.4 \mu \mathrm{g} \mathrm{L}^{-1}$ and LOQ $=$ $4.8 \mu \mathrm{g} \mathrm{L}^{-1}$ for $\mathrm{Al}$, and LOD $=0.5 \mu \mathrm{g} \mathrm{L}^{-1}$ and $\mathrm{LOQ}=1.6 \mu \mathrm{g} \mathrm{L}^{-1}$ for $\mathrm{Pb}$. These values for the limits and quantification are well suited for work with beverage samples.

The characteristic mass of $16.3 \pm 0.7 \mathrm{pg}$ for $\mathrm{Al}$ and $9.8 \pm 0.6 \mathrm{pg}$ for $\mathrm{Pb}$ was in accordance with the recommended value for the lead aqueous standard, where the characteristic mass recommended is $10.0 \mathrm{pg}$ for both analytes. For aluminum, the value is higher than that recommended, but is yet appropriate considering that the result was obtained with nondiluted beer samples, and the recommended result is obtained with aqueous standards.

Recovery as well as intra-assay and inter-assay studies were carried out for beer samples. To conduct the intra-assay studies, 15 replicates of the same sample were prepared as described above and spiked in three different concentration levels (30, 50, and $80 \mu \mathrm{g} \mathrm{L}^{-1}$ for $\mathrm{Al}$, and 15, 30 , and $55 \mu \mathrm{g} \mathrm{L}^{-1}$ for $\mathrm{Pb}$ ). Each reading was done in triplicate. Thus, the intra-assay part of the study analyzed 15 replicates of the same sample at three different levels within the calibration range and read in triplicate $(n=15$ for each sample, considering that the total number of readings was 45 ).

According to the inter-assay arm of the study, the same procedure was repeated over three consecutive days resulting in $\mathrm{n}$ for each level of 15 , considering that there were 45 replicate readings. The total $\mathrm{n}$ for all results was 135 . The obtained range value for recovery was 89 $-95 \%$ for $\mathrm{Al}$ and $97-98 \%$ for $\mathrm{Pb}$ $(n=45)$. The average coefficients of variation were 4.0 and $3.0 \%$ for intra- and inter-assay precision for

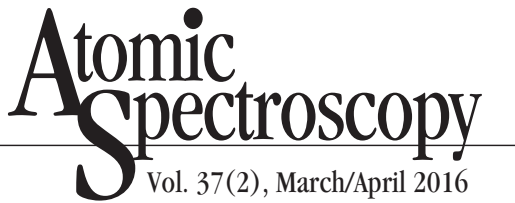

$\mathrm{Al}$, and 2.5 and 5.0 for intra- and inter-assay precision for lead, which was within the acceptable range (43-45). To check the accuracy of the proposed methodologies, recovery studies were conducted with samples spiked with three concentration levels for both analytes. As previously mentioned, the recoveries for $\mathrm{Al}$ and $\mathrm{Pb}$ are close to $100 \%$. Table VIII summarizes the analytical figures of merit for the proposed methods in these studies.

\section{Analytical Application}

Optimized experimental conditions for the multivariate procedure were used in the determination of $\mathrm{Al}$ and $\mathrm{Pb}$ (see Table II) in national and imported bottled and canned beer samples purchased at a local liquor store. The concentrations of $\mathrm{Al}$ and $\mathrm{Pb}\left(\mu \mathrm{g} \mathrm{L}^{-1}\right)$ obtained are listed in Table IX. For all of the analyzed beers, the values were between <LOQ to 72.2 for Al. Higher values were obtained in beer stored in cans (national and imported). For lead, the obtained values in the analyzed beer samples varied between $<$ LOQ to 8.7. The value observed in nationally produced canned beer was higher.

Coelho et al. (6) proposed a method to determine lead in beer samples after solid-phase extraction and FAAS, where the authors needed to optimize many variables Their system by solid-phase extraction is interesting, but the determination of lead is very laborious and not applicable for quality control of metals in beer samples.

The method presented by Hernandez-Artiga et al. (49) uses expensive instrumentation, is timeconsuming, prone to contamination or loss by volatilization. In comparison, the proposed method in this work is much simpler and requires no prior sample digestion.

Wu et al. (50) also report of a laborious method that requires preconcentration in the surface of sil- 
TABLE VIII

\section{Analyrical Figures of Merit for the Method of Determination} of $\mathrm{Al}$ and $\mathrm{Pb}$ in Beer Samples by GFAAS

\begin{tabular}{|c|c|c|}
\hline Parameters & Results for Al & Results for $\mathrm{Pb}$ \\
\hline Regression equation $(n=3)$ & $Y=0.0070^{*} x+0.144$ & $Y=0.087^{*} x+0.0043$ \\
\hline $\mathrm{R}^{2}(\mathrm{n}=3)$ & $0.9966 \pm 0.0036$ & $0.9947 \pm 0.0023$ \\
\hline Working range $\left(\mu \mathrm{g} \mathrm{L}^{-1}\right)$ & $0-90$ & $0-60$ \\
\hline $\operatorname{LOD}\left(\mu \mathrm{g} \mathrm{L}^{-1}\right)$ & 1.4 & 0.5 \\
\hline $\operatorname{LOQ}\left(\mu \mathrm{g} \mathrm{L}^{-1}\right)$ & 4.8 & 1.6 \\
\hline Characteristic range $(n=6, p$ & & $16.3 \pm 5.69 .8 \pm 0.6$ \\
\hline $\begin{array}{l}\text { Coefficient of variation } \\
\text { intra-assay average concentratio } \\
\text { of } 20,50 \text { and } 80 \mu \mathrm{g} \mathrm{L}^{-1} \text { of } \mathrm{Al} \text { and } \\
15,30 \text { and } 55 \mu \mathrm{L} \mathrm{L}^{-1} \text { for } \mathrm{Pb}(\mathrm{n}=\end{array}$ & $\begin{array}{l}4.0 \\
\text { ns } \\
5)^{\mathrm{b}}\end{array}$ & 2.5 \\
\hline $\begin{array}{l}\text { Mean coefficient of variation } \\
\text { inter-assay concentrations of } \\
20,50 \text { and } 80 \mu \mathrm{g} \mathrm{L}^{-1} \text { for } \mathrm{Al} \text { and } \\
15,30 \text { and } 54 \mu \mathrm{g} \mathrm{L}^{-1} \text { for } \mathrm{Pb}(\mathrm{n}=\end{array}$ & 3.0 & 3.1 \\
\hline $\begin{array}{l}\text { Percent range recovery (\%) } \\
(3 \text { levels, } n=5 \text { per level) }\end{array}$ & $89-95$ & $97-98$ \\
\hline
\end{tabular}

TABLE IX

Determination of $\mathrm{Al}$ and $\mathrm{Pb}$ in Beer Samples by GFAAS in Can (C), Bottle (B), National (N), Imported (I)

\begin{tabular}{|c|c|c|}
\hline Samples & $\begin{array}{l}\text { Determined Value } \\
\left(\mu \mathrm{L} \mathrm{L}^{-1}\right) \text { for } \mathrm{Al} \\
\mathrm{n}=3 \text { Samples }\end{array}$ & 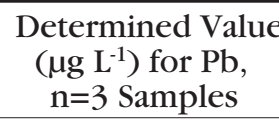 \\
\hline $1 \mathrm{CN}$ & $<$ LOQ & $1.5 \pm 0.2$ \\
\hline $2 \mathrm{BI}$ & $<\mathrm{LOQ}$ & $<$ LOQ \\
\hline $3 \mathrm{CN}$ & $<\mathrm{LOQ}$ & $2.5 \pm 0.2$ \\
\hline $4 \mathrm{CN}$ & $6.8 \pm 0.1$ & $3.9 \pm 0.3$ \\
\hline $5 \mathrm{BI}$ & $<$ LOQ & $0.7 \pm 0.1$ \\
\hline $6 \mathrm{CN}$ & $<\mathrm{LOQ}$ & $8.7 \pm 0.1$ \\
\hline $7 \mathrm{BI}$ & $<$ LOQ & $1.1 \pm 0.1$ \\
\hline $8 \mathrm{BN}$ & $12.0 \pm 0.9$ & $0.5 \pm 0.1$ \\
\hline $9 \mathrm{BN}$ & $14.9 \pm 0.2$ & $1.3 \pm 0.1$ \\
\hline $10 \mathrm{BI}$ & $10.4 \pm 0.6$ & $1.1 \pm 0.1$ \\
\hline $11 \mathrm{CI}$ & $22.6 \pm 1.1$ & $1.0 \pm 0.1$ \\
\hline $12 \mathrm{BN}$ & $33.4 \pm 0.8$ & $3.2 \pm 0.3$ \\
\hline $13 \mathrm{CI}$ & $36.2 \pm 1.2$ & < LOQ \\
\hline $14 \mathrm{BN}$ & $12.4 \pm 0.4$ & $7.8 \pm 0.7$ \\
\hline $15 \mathrm{CI}$ & $63.4 \pm 0.7$ & $5.1 \pm 0.7$ \\
\hline $16 \mathrm{CN}$ & $72.9 \pm 1.2$ & $6.1 \pm 0.6$ \\
\hline $17 \mathrm{BN}$ & $22.6 \pm 0.6$ & $3.1 \pm 0.3$ \\
\hline $18 \mathrm{CN}$ & $55.2 \pm 1.6$ & $0.7 \pm 0.1$ \\
\hline $19 \mathrm{BN}$ & <LOQ & $3.4 \pm 0.4$ \\
\hline $20 \mathrm{BN}$ & $<\mathrm{LOQ}$ & $2.4 \pm 0.3$ \\
\hline $21 \mathrm{BN}$ & $18.8 \pm 0.5$ & $6.0 \pm 0.2$ \\
\hline
\end{tabular}

ica gel during the chemical modification and elution of the analyte (lead) and nitric acid solution was used. This is not an efficient method for routine use in quality control of lead in beverages (tea and beer).

Westerlund and Jagner (51) proposed a method to determine lead, cadmium, and copper by potentiometric stripping analysis. This method is not very common for use in the quality control of heavy metals, and the results, compared with atomic absorption, shows a discrepancy of about $15 \%$. GFAAS today is a more commonly used technique for quality control of toxic metals in various foods and beverages and is simple, very accurate, and available in routine laboratories.

\section{CONCLUSION}

The procedures developed in this study using chemometric tools to optimize the variables for the determination of aluminum and lead in beer samples by graphite furnace atomic absorption spectrometry offer low limits of detection and quantification, good sensitivity, low precision, and good reproducibility. The use of chemometric optimization allows the development of good methods to determine $\mathrm{Al}$ and $\mathrm{Pb}$ in beer. The use of a permanent modifier represents a good tool because corrected background absorption was obtained, good peak profile, in addition to good sensitivity for the two investigated elements. Under these conditions, the matrix effects were eliminated in the determination of aluminum, and aqueous solutions can be used for calibration with accuracy, precision, and sensitivity. Therefore, the standard addition technique was required for lead determination in these beer samples.

The aluminum and lead concentrations in the analyzed beer samples were very low. However, 
considering the high consumption of this beverage by the Brazilian population, beer represents an important source of intake of these potentially toxic metals at low concentrations. Unfortunately, the Brazilian legislation does not provide maximum tolerable intake levels for these metals in commercial drinks or food.

\section{ACKNOWLEDGMENT}

We are grateful for the financial support and scholarship from the Conselho Nacional de Desenvolvimento Científico e Tecnológico (CNPq), Coordenação de Aperfeiçoamento de Pessoal de Nivel Superior (CAPES), and the Fundação de Amparo à Pesquisa do Estado de Minas Gerais (FAPEMIG). J. B. B. da Silva wishes to thank $\mathrm{CNPq}$ for the research grant.

\section{Received July 31, 2015.}

\section{REFERENCES}

1. P. Pohl, Food Add. Contaminants 25,693 (2008)

2. Supra-Regional Assay Service: Centers for Analyzes and Clinical Interpretation. 2008, http://www.sasntre.org/assays/ trace_metals/lead.html. (Accessed in 10/09/2013).

3. R. L. Poole, K. P. Pieroni, S. Gaskari, T. K. Dixon, K. T. Park, and J. A. Kerner, Jr., Nutrients 16, 92 (2011).

3. F. R. de Amorim, C. C. Nascentes, M. B. Franco, and J. B. B. Silva, Intern. J. Spectrosc., Article ID 810641, 1 (2011).

4. B. Welz and M. Sperling, in Atomic Absorption Spectrometry, 3rd ed., Wiley-VCH, Weinheim, Germany (1999).

5. V. N. Alves, S. S. O. Borges, W. B. Neto, and N. M. M. Coelho, J. Autom. Methods Managements Chem., Article ID 464102, 1 (2011).
6. M. B. Dessuy, M. G. R. Vale, B. Welz, A. R. Borges, M. M. Silva, and P. B. Martelli, Talanta 85, 681 (2011).

7. J. S. Carletto, E. Carasek, and B. Welz, Talanta 84, 989 (2011).

8. C. C. Nascentes, M. Y. Kamogawa, K. G. Fernandes, M. A. Z. Arruda, A. R. N. Nogueira, and J. A. Nóbrega, Spectrochim. Acta Part B, 60, 749 (2005).

10. J. B. B. Silva, M. A. M. Silva, A. J. Curtius, and B. Welz, J. Anal. At. Spectrom. 14, 1737 (1999).

11. J. B. B. Silva, M. B. O. Giacomelli, I. G. de Souza, and A. J. Curtius, Microchem. J. 60, 249 (1998).

12. F. G. Pinto, U. V. Rey, D. Andrada, and J. B. B. Silva, Eclética Química 30, 59 (2006) .

13. A. B. Volynsky, Spectrochim. Acta Part B, 55, 103 (2000).

14. H. M. Ortner, E. Bulska, U. Rohr, G. Schlemmer, S. Weinbruch, and B. Welz, Spectrochim. Acta Part B, 57, 1835 (2002).

15. R. E. S. Fróes and C. C. Windmöller, and J. B. B. Silva, Revista Analytica 23, 32 (2006)

16. M. B. O. Giacomelli, M. C. Lima, V. Stupp, J. B. B. Silva, and P. Barmejo-Barrera, Spectrochim Acta Part B, 57, 2151 (2002).

17. B. R. Nunes, C. G. Magalhães, and J. B. B. Silva, J. Anal. At. Spectrom. 17, 1335 (2002).

18. C. G. Magalhães, K. L. A. Lelis, and J. B. B. Silva, Anal. Bioanal. Chem. 374, 1301 (2002).

19. C. G. Magalhães, K. L. A. Lelis, C. A. Rocha, and J. B. B. Silva, Anal. Chem. Acta 464, 323 (2002).

20. C. G. Magalhães, B. R. Nunes, M. B. O. Giacomelli, and J. B. B. Silva, J. Anal. At. Spectrom. 18, 787 (2003).

21. J. B. B. Silva, M. A. M. Veiga, D. Galindo, A. J. Curtius, and B. Welz, Talanta 60, 977 (2003).

22. M. B. O. Giacomelli, J. B. B. Silva, T. Saintpierre, A. J. Curtius, and B. Welz, Microchem. J. 77, 151 (2004).

23. G. Pinto, D. Andrada, C. G. Magalhães, B. R. Nunes, F. R. Amorim, M. B. Franco, T. Saintpierre, J. B. B.

\section{Atomic \\ Mpectroscopy \\ $\bigcup$ Vol. 37(2), March/April 2016}

Silva, and A. J. Curtius, Anal. Bioanal. Chem. 383, 825 (2005).

24. J. B. B. Silva. R. O. Bejarano, C. Demichelli, and F. Frezard, At. Spectroscopy. . 27, 93 (2006).

25. F. G. Pinto, D. Andrada, U. V. Rey, L. M. Ansaloni, and J. B. B. Silva, Anal. Lett. 39, 2441 (2006).

26. D. Andrada, F. G. Pinto, C. G. Magalhães, B. R. Nunes, M. B. Franco, and J. B. B. Silva, J. Braz. Chem. Soc. 17, 328 (2006).

27. H. J. F. Fabrino, W. Borges, S. S. O. Borges, A. Goes, and J. B. B. Silva, At. Spectrosc. 25, 227 (2007).

28. P. C. Lara, J. Niccacio, W. Borges, and J. B. B. Silva, Anal. Lett. 42, 923 (2009).

29. R. F. de Oliveira, C. C. Windmöller, W. B. Neto, C. C. de Souza, M. A. Beiner,and J. B. B. Silva, Anal. Methods 5, 5746 (2013).

30. P. C. P. Lara, J. N. Silveira, W. B. Neto, M. A. Beinner, and J. B. B. Silva, Food Anal. Methods 29, 609 (2013).

31. C. C. de Souza, J. H. F. Fabrino, M. A. Beinner, W. B. Neto, S. D. Cangussu, W. L. Tafuri, and J. B. B. Silva, Anal. Methods 5, 2129 (2013).

32. L. A. Pereira, I. Amorim, and J. B. B. Silva, Talanta 65, 395 (2004).

33. L. A. Pereira, I. Amorim, and J. B. B. Silva, Talanta 68, 771 (2006).

34. L. A. Pereira, S. S. O. Borges, M. Castro, W. Borges, C. C. Windmöller, and J. B. B. Silva, Can. J. Chem. 86, 312 (2008).

35. M. H. Canuto, G. M. Lima, H. G. L. Siebald, and J. B. B. Silva, J. Anal. At. Spectrom. 18, 1404 (2003).

36. D. A. Maria, M. C. E. Rollerberg, and J. B. B. Silva, At. Spectroscopy.. 26, 151 (2005).

37. F. R. Amorim, C. Boff, M. B. Franco, J. B. B. Silva, and C. C. Nascentes, Microchem. J. 82, 168 (2006).

38. J. N. Silveira, P. C. Lara, C. Nascentes. C. Demichelli, and J. B. B. Silva, Can. J. Chem. 85, 619 (2007). 
39. J. N. Silveira, P. C. Lara, M. B. Dias, C. Nascentes, C. Demichelli, and J. B. B. Silva, Anal. Lett. 40, 1736 (2007).

40. D. Jagner and S. Westerlund, Anal. Chim. Acta 117, 159-164 (1980).

41. Dell, Inc., STATISTICA for Windows - http://www.statsoft.com (2001).

42. Guidance for the Validation of Analytical Methodology and Calibration of Equipment used for Testing of Illicit Drugs in Seized Materials and Biological Specimens, New York, USA, p. 12 (2009)

43. R. J. Causon, J. Chromatogr. B. 689,175(1997).

44. A. A. M. Chasim, E. S. Nascimento, L. M. R. Neto, M. E. P. B. Siqueira, M. H. Andraus, M. C. Salvadori, N. A. G. Fernicola, R. Gorni, and S. Salcedo, Rev. Bras. Tox. 11, 1 (1999).

45. S. C. N. Queiroz, C. H. Collins, and I. S. F. Jardim, Quim. Nova 1, 68 (2001).

46. AOAC (Association of Official Analytical Chemists), Peer-verified Methods Program, Manual on Policies and Procedures, Arlington, VA, USA (1993)

47. http://www.epa.gov/osw/ hazard/testmethods/sw846/pdfs/3 060a.pdf Section 8.3, p. 3060A-7. (Accessed in 14/11/2014).

48. F. F. Lopez, C. Cabrera, M. L. Lorenzo, and M. C. Lopez, Sci. Total Environm. 220, 1 (1998).

49. D. Bellido-Mila, J. M. Moreno-Perez, and M. P. Hernández-Artiga, Spectrochim. Acta Part B, 55, 855 (2000).

50. J. Cheng, X. Ma, and Y. Wu, Food Anal. Methods 7, 1083 (2014).

51. S. Westerlund and D. Jagner, Anal. Chim. Acta 117, 159 (1980) 